\title{
Karakteristik Ukuran Partikel dan Indeks Polidispersitas Formulasi Nanoemulsi Pewarna Alam Ekstrak Kayu Secang (Caesalpinia Sappan Linn)
}

\author{
Muhammad Rusdi ${ }^{1}$ \\ 1 Program Studi Teknik Pertanian, Sekolah Tinggi Pertanian Kutai Timur \\ JIn. Soekarno Hatta Sangatta, Kutai Timur, Kalimantan Timur, Kode Pos 75387 \\ email: m.rusdi@stiperkutim.ac.id
}

\begin{abstract}
This research aims to obtain nanoemulsion formulation design natural dyes extract the sappan wood, which involves determining the optimal conditions formulation nanoemulsion, observation of stability that occurs in formulation nanoemulsion to produce emulsion dyes. Sappan extract formulated into nanoemulsion with a fixed concentration of $10 \%$ of the weight of the formulation, emulsifier used is Span20, Span80, Tween20 and Tween 80 with a percentage of 2.5\%, 5\%, and $10 \%$ of the weight of the formula to single formulation and $1.25 \%, 2.5 \%$, and $5 \%$ of the weight formula for dual formulation, while the solvent used was distilled water with a percentage of $87.50 \%, 85.00 \%$, and $80.00 \%$ of the weight of the formula. Preliminary results with visual observation/visible, showing that the best formulation is the formulation of Tween20 (10\%), formulation Tween80 (10\%), formulation Span20Span80 (1.25\%), formulation Span20-Tween80 (5\%), formulation Span80-Tween20 (5\%), formulation Span80-Tween80 (5\%), and the formulation Tween20-Tween80 (5\%). Results of particle size, measurements showed a single formulation using emulsifier Tween and double combination formulation Tween-Tween produces formula nanoemulsion with a larger particle size diameter $>100 \mathrm{~nm}$ ), the double combination formulation Span-Span and Span-Tween produce formula nanoemulsion with a smaller particle size diameter $(<100 \mathrm{~nm})$. The measurement results show the value of the particle size distribution polydispersity indeks values of the seven formulations nanoemulsion between 0.187 to 0.782 , these states generally formulation nanoemulsion meets all standards as the particle size distribution of system nanoemulsion.
\end{abstract}

Keywords: Sappan extract, the type and concentration of emulsifier, the concentration of distilled water, nanoemulsion, natural dyes

\begin{abstract}
ABSTRAK
Penelitian ini bertujuan untuk memperoleh desain formulasi nanoemulsi pewarna alam menggunakan ekstrak kayu secang, yang meliputi penentuan kondisi formulasi nanoemulsi yang optimal, pengamatan stabilitas yang terjadi pada formulasi nanoemulsi dalam menghasilkan emulsi pewarna. Ekstrak Secang diformulasikan menjadi nanoemulsi dengan konsentrasi yang tetap 10\% dari berat formula, emulsifier yang digunakan adalah Span20, Span80, Tween20, dan Tween80 dengan presentase $2,5 \%, 5 \%$, dan $10 \%$ dari berat formula untuk formulasi tunggal dan $1,25 \%, 2,5 \%$, dan $5 \%$ dari berat formula untuk formulasi ganda, sedangkan zat pelarut yang digunakan adalah akuades dengan presentase $87,50 \%, 85,00 \%$, dan $80,00 \%$ dari berat formula. Hasil penelitian awal dengan pengamatan secara visual/kasat mata, menunjukkan bahwa formulasi yang terbaik adalah formulasi Tween20 (10\%), formulasi Tween80 $(10 \%)$, formulasi Span20-Span80 (1,25\%), formulasi Span20-Tween80 (5\%), formulasi Span80-Tween20 (5\%), formulasi Span80-Tween80 (5\%), dan formulasi Tween20-Tween80 (5\%). Hasil pengukuran ukuran partikel, menunjukkan formulasi tunggal menggunakan emulsifier Tween dan formulasi ganda kombinasi TweenTween menghasilkan formula nanoemulsi dengan diameter ukuran partikel lebih besar $(>100 \mathrm{~nm}$ ), formulasi ganda kombinasi Span-Span dan Span-Tween menghasilkan formula nanoemulsi dengan diameter ukuran partikel lebih kecil $(<100 \mathrm{~nm})$. Hasil pengukuran nilai distribusi ukuran partikel menunjukkan nilai indeks polidispersitas dari ketujuh formulasi nanoemulsi antara 0,187 sampai 0,782 , ini menyatakan secara umum semua formulasi nanoemulsi memenuhi standar distribusi ukuran partikel sebagai sistem nanoemulsi.
\end{abstract}


Kata kunci: Ekstrak secang, jenis dan konsentrasi emulsifier, konsentrasi akuades, nanoemulsi, pewarna alam

\section{Pendahuluan}

\subsection{Latar Belakang}

Indonesia sebagai salah satu negara tropis memiliki potensi besar untuk dapat menghasilkan dan membuat zat warna alam yang ramah lingkungan dengan memanfaatkan berbagai sumberdaya yang sudah tersedia di alam. Setiap proses dalam pembuatan zat warna alam dapat memanfaatkan bahan-bahan alam yang ada di lingkungan sekitar sebagai pengganti bahan-bahan sintetik sehingga pencemaran lingkungan dapat diminimalkan. Upaya memproduksi zat warna alam yang ramah lingkungan dapat dilakukan dengan menggunakan warna-warna yang diperoleh dari hasil ekstrak bagian-bagian tumbuhan yang memiliki kandungan pigmen dengan warna yang menarik. Zat pewarna alam pada umumnya diperoleh dari hasil ekstrak berbagai bagian tumbuhan, salah satunya adalah dari kayu secang (Caesalpinia sappan $\mathrm{L}$ ).

Namun, terdapat beberapa kendala dengan menggunakan zat warna alam antara lain: prosesnya tidak praktis, ketersediaan variasi warnanya agak terbatas hanya untuk warna-warna cerah, dan ketersediaan bahannya yang tidak siap pakai. Hal inilah yang membuat diperlukannya proses-proses dan desain formulasi khusus agar pewarna alami dapat dijadikan sebagai pewarna yang efektif, efisien dan berkualitas. Sebagai upaya mengangkat kembali penggunaan zat warna alam, maka perlu dilakukan pengembangan teknologi agar kendala-kendala yang terjadi dapat diatasi. Teknologi yang sedang menjadi tren akhir-akhir ini adalah nanoteknologi. Nanoteknologi secara umum dapat didefinisikan sebagai perancangan, pembuatan, dan aplikasi struktur/material yang berdimensi nanometer.

Nanoemulsi adalah suatu sistem dispersi minyak dengan air yang distabilkan oleh lapisan antarmuka dari molekul surfaktan. Surfaktan yang digunakan dapat tunggal, campuran, atau kombinasi dengan zat tambahan lain. Nanoemulsi merupakan suatu sistem dispersi yang dikembangkan dari sediaan emulsi. Tetapi karakteristik sediaan nanoemulsi memiliki banyak kelebihan dibandingkan dengan emulsi biasa. Karakteristik tersebut antara lain bersifat stabil secara termodinamika, jernih, transparan atau translucent, viskositasnya rendah, serta mempunyai tingkat solubilisasi yang tinggi (Bakan, 1995; Ping Li et all 2005; Lawrence \& Rees 2000).

Nanoteknologi ini diterapkan pada sistem nanoemulsi yang dibuat dari ekstrak kayu secang yang sudah diekstraksi, nanoemulsi sendiri tidak hanya sebatas bagaimana menghasilkan material atau partikel emulsi yang berukuran nanometer, melainkan bagaimana cara memproduksi serta mengetahui kegunaan dari sifat baru yang muncul dari material nano yang telah dibuat. Untuk mengaplikasikan pewarna alami dengan 
sistem nanoemulsi, perlu dilakukan penelitian lebih lanjut tentang desain formulasi dan proses yang dibutuhkan agar kegunaan dan sifat baru yang muncul dapat mengatasi kelemahan pada zat pewarna alami.

Berdasarkan dari analisa di atas, maka perlu dikembangkan sebuah penelitian teknologi nanoemulsi untuk membuat zat pewarna alami yang baik untuk menggantikan zat warna sintesis yang selama ini digunakan. Alasan diatas mendorong diadakannya penelitian tentang "Karakteristik Ukuran Partikel dan Indeks Polidispersitas Formulasi Nanoemulsi Pewarna Alam Ekstrak Kayu Secang (Caesalpinia Sappan Linn)"

\subsection{Tujuan Penelitian}

Penelitian ini bertujuan untuk memperoleh karakteristik ukuran partikel dan indeks polidispersitas formulasi nanoemulsi pewarna alam menggunakan ekstrak kayu secang, yang meliputi penentuan komposisi formulasi nanoemulsi yang optimal, pengamatan stabilitas yang terjadi pada formulasi nanoemulsi dalam menghasilkan emulsi pewarna dan karakterisasi nanoemulsi yang dihasilkan.

\subsection{Manfaat Penelitian}

Dalam penelitian karakteristik ukuran partikel dan indeks polidispersitas formulasi nanoemulsi pewarna alam menggunakan bahan baku kayu secang, maka manfaat dari penelitian ini adalah menghasilkan desain formulasi nanoemulsi zat pewarna alam untuk pewarnaan yang efisien, ramah lingkungan dan tepat guna.

\subsection{Ruang Lingkup Penelitian}

Dalam penelitian karakteristik ukuran partikel dan indeks polidispersitas formulasi nanoemulsi pewarna alam menggunakan bahan baku kayu secang, maka ruang lingkup dari penelitian ini adalah:

a. Komposisi formulasi nanoemulsi berdasarkan jenis dan persentase surfaktan yang digunakan.

b. Mengamati stabilitas nanoemulsi untuk menentukan komposisi yang menghasilkan nanoemulsi.

c. Karakterisasi ukuran partikel, stabilitas emulsi dan indeks polidispersitas dalam menghasilkan emulsi pewarna.

\subsection{Hipotesis Penelitian}

Dalam penelitian karakteristik ukuran partikel dan indeks polidispersitas formulasi nanoemulsi pewarna alam menggunakan bahan baku kayu secang, maka hipotesis dari penelitian ini adalah:

1. Komposisi surfaktan, ekstrak secang dan pelarut berpengaruh terhadap pembentukan nanoemulsi. 
2. Formulasi nanoemulsi yang stabil memiliki karakteristik ukuran partikel dan indeks polidispersitas tertentu yang sesuai dengan standar teknologi nanoemulsi (nanoteknologi) yang aman.

\section{Metodologi Penelitian}

\subsection{Waktu dan Tempat Penelitian}

Penelitian ini dilaksanakan pada bulan Oktober 2013 sampai Desember 2013 di dua lokasi berbeda, yaitu di Laboratorium Balai Besar Penelitian dan Pengembangan Pascapanen Pertanian Bogor dan Laboratorium PUSPITEK Serpong Tanggerang.

\subsection{Bahan dan Alat}

Bahan yang digunakan dalam penelitian adalah kayu secang yang akan diekstraksi di laboratorium Balai Besar Pasca Panen, bahan pelarut yang akan digunakan adalah: Aquades, metanol, dan jenis surfaktan yang digunakan adalah Tween 20 dan 80, serta Span 20 dan 80.

Peralatan yang digunakan dalam penelitian ini adalah alat untuk ekstraksi, evaporator, termometer, timbangan, peralatan gelas (gelas ukur, gelas pengaduk, dan lain-lain), mikroskop polaritas, viskometer, refraktometer, spektrofotometer, chromameter, partikel analyzer, neraca analitik dan perangkat pendukung lainnya.

Adapun tahapan penelitian adalah sebagai berikut:

\section{Tahap pertama: Proses Ekstraksi Kayu Secang}

Kayu secang sebagai bahan baku terlebih dahulu diekstraksi dengan menggunakan pelarut metanol (dengan teknik maserasi). Kayu secang yang sudah dipilih untuk diekstraksi dipotong, kemudian dilakukan penggilingan (menghasilkan bubuk dengan ukuran 40 mesh). Selanjutnya diekstraksi selama 12 jam dengan perbandingan bubuk dan pelarut (metanol) 1:6, lalu dilakukan penyaringan untuk memisahkan ampas dan hasil ekstrak encer, selanjutnya dilakukan penguapan dengan kondisi vakum $\left(50^{\circ} \mathrm{C}\right)$ untuk menguapkan pelarut metanol dan menghasilkan ekstrak pekat ( $20^{\circ}$ brix).

\section{Tahap kedua: Proses Pembuatan Nanoemulsi}

1. Pembuatan formula Span20.

Tabel 1. Formulasi Span20

\begin{tabular}{cccc}
\hline Bahan & Formula 1 & Formula 2 & Formula 3 \\
\hline Ekstrak secang & 10,00 & 10,00 & 10,00 \\
Span20 & 2,50 & 5,00 & 10,00 \\
Akuades & 87,50 & 85,00 & 80,00 \\
Total & 100,00 & 100,00 & 100,00 \\
\hline
\end{tabular}


2. Pembuatan formula Span80.

Tabel 2. Formulasi Span80

\begin{tabular}{cccc}
\hline Bahan & Formula 1 & Formula 2 & Formula 3 \\
\hline Ekstrak secang & 10,00 & 10,00 & 10,00 \\
Span80 & 2,50 & 5,00 & 10,00 \\
Akuades & 87,50 & 85,00 & 80,00 \\
Total & 100,00 & 100,00 & 100,00 \\
\hline
\end{tabular}

3. Pembuatan formula Tween20.

Tabel 3. Formulasi Tween20

\begin{tabular}{cccc}
\hline Bahan & Formula 1 & Formula 2 & Formula 3 \\
\hline Ekstrak secang & 10,00 & 10,00 & 10,00 \\
Tween20 & 2,50 & 5,00 & 10,00 \\
Akuades & 87,50 & 85,00 & 80,00 \\
Total & 100,00 & 100,00 & 100,00 \\
\hline
\end{tabular}

4. Pembuatan formula Tween80.

Tabel 4. Formulasi Tween80

\begin{tabular}{cccc}
\hline Bahan & Formula 1 & Formula 2 & Formula 3 \\
\hline Ekstrak secang & 10,00 & 10,00 & 10,00 \\
Tween80 & 2,50 & 5,00 & 10,00 \\
Akuades & 87,50 & 85,00 & 80,00 \\
Total & 100,00 & 100,00 & 100,00 \\
\hline
\end{tabular}

5. Pembuatan formula Span20,Span80.

Tabel 5. Formulasi Span20-Span80

\begin{tabular}{cccc}
\hline Bahan & Formula 1 & Formula 2 & Formula 3 \\
\hline Ekstrak secang & 10,00 & 10,00 & 10,00 \\
Span20 & 1,25 & 2,50 & 5,00 \\
Span80 & 1,25 & 2,50 & 5,00 \\
Akuades & 87,50 & 85,00 & 80,00 \\
Total & 100,00 & 100,00 & 100,00 \\
\hline
\end{tabular}

6. Pembuatan formula Span20,Tween20.

Tabel 6. Formulasi Span20-Tween20

\begin{tabular}{cccc}
\hline Bahan & Formula 1 & Formula 2 & Formula 3 \\
\hline Ekstrak secang & 10,00 & 10,00 & 10,00 \\
Span20 & 1,25 & 2,50 & 5,00 \\
Tween20 & 1,25 & 2,50 & 5,00 \\
Akuades & 87,50 & 85,00 & 80,00 \\
Total & 100,00 & 100,00 & 100,00 \\
\hline
\end{tabular}

7. Pembuatan formula Span20,Tween80.

Tabel 7. Formulasi Span20,Tween80

\begin{tabular}{cccc}
\hline Bahan & Formula 1 & Formula 2 & Formula 3 \\
\hline Ekstrak secang & 10,00 & 10,00 & 10,00 \\
Span20 & 1,25 & 2,50 & 5,00 \\
Tween80 & 1,25 & 2,50 & 5,00 \\
Akuades & 87,50 & 85,00 & 80,00 \\
Total & 100,00 & 100,00 & 100,00 \\
\hline
\end{tabular}

8. Pembuatan formula Span80,Tween20.

Tabel 8. Formulasi Span80,Tween20

\begin{tabular}{cccc}
\hline Bahan & Formula 1 & Formula 2 & Formula 3 \\
\hline Ekstrak secang & 10,00 & 10,00 & 10,00 \\
Span80 & 1,25 & 2,50 & 5,00 \\
Tween20 & 1,25 & 2,50 & 5,00 \\
Akuades & 87,50 & 85,00 & 80,00 \\
Total & 100,00 & 100,00 & 100,00 \\
\hline
\end{tabular}


9. Pembuatan formula Span80,Tween80.

Tabel 9. Formulasi Span80,Tween80

\begin{tabular}{cccc}
\hline Bahan & Formula 1 & Formula 2 & Formula 3 \\
\hline Ekstrak secang & 10,00 & 10,00 & 10,00 \\
Span80 & 1,25 & 2,50 & 5,00 \\
Tween20 & 1,25 & 2,50 & 5,00 \\
Akuades & 87,50 & 85,00 & 80,00 \\
Total & 100,00 & 100,00 & 100,00 \\
\hline
\end{tabular}

10. Pembuatan formula Tween20,Tween80.

Tabel 10. Formulasi Tween20,Tween80

\begin{tabular}{cccc}
\hline Bahan & Formula 1 & Formula 2 & Formula 3 \\
\hline Ekstrak secang & 10,00 & 10,00 & 10,00 \\
Tween20 & 1,25 & 2,5 & 5,00 \\
Tween80 & 1,25 & 2,5 & 5,00 \\
Akuades & 87,50 & 85,00 & 80,00 \\
Total & 100,00 & 100,00 & 100,00 \\
\hline
\end{tabular}

Keterangan: presentase dalam persen (\%)

\section{Tahap ketiga: Proses Analisis (Karakterisasi)}

Pada tahap ini hasil yang didapat akan dilakukan analisis, dengan paremeter yang akan dianalisis antara lain: Ukuran partikel, stabilitas emulsi dan indeks polidispersitas.

\subsection{Pengolahan Data}

Dalam pengolahan data yang dihasilkan digunakan rancangan percobaan RAL (Rancangan Acak Lengkap) dengan model linear:

Dimana :

$$
Y_{i j}=\mu+T i+\varepsilon i j
$$

$Y_{\mathrm{ij}}=$ Hasil parameter yang akan diukur (Ukuran partikel, stabilitas emulsi, intensitas warna dan viskositas)

$\mu=$ rataan tengah populasi

$\mathrm{Ti}=$ pengaruh dari perlakuan ke-i (Pengaruh formulasi ke- i)

$\varepsilon i j=$ pengaruh acak dari perlakuan ke-i ulangan ke-j

\section{Hasil dan Pembahasan}

\subsection{Karakteristik Kayu Secang (Ekstrak Secang)}

Kayu secang (Caes/pinia Sappan L.) menghasilkan pigmen berwarna merah bernama Brazilein $\left(\mathrm{C}_{16} \mathrm{H}_{14} \mathrm{O}_{5}\right)$. Pigmen ini memiliki warna merah tajam dan cerah pada $\mathrm{pH}$ netral ( $\mathrm{pH}$ 6-7) dan bergeser kearah merah keunguan dengan semakin meningkatnya $\mathrm{pH}$. Pada $\mathrm{pH}$ rendah $(\mathrm{pH} 2-5)$ Brazilein memiliki warna kuning. Kayu secang yang digunakan dalam pembutan ekstrak kayu secang yaitu dalam bentuk serutan kayu yang tidak diberi perlakuan apapun. Pada pembuatan ekstrak kayu secang tidak dilakukan penyimpanan akan tetapi dilakukan pembuatan ekstrak kayu secang setiap kali akan digunakan, karena untuk mencegah terjadinya perubahan warna ekstrak kayu secang.

Pada pembuatan ekstrak kayu secang dalam penelitian ini terlebih dahulu memilih kayu secang sebagai bahan baku yang akan dilakukan proses ekstraksi dengan menggunakan methanol sebagai pelarut (teknik maserasi), kayu secang yang sudah dipilih kemudian dipotong-potong lalu dilakukan penggilingan menghasilkan bubuk 
dengan ukuran 40 mesh, selanjutnya diekstraksi selama 12 jam dengan perbandingan bubuk dan pelarut methanol 1:6, kemudian dilakukan penyaringan untuk memisahkan ampas dan hasil ekstrak encer, setelah itu dilakukan penguapan dengan kondisi vakum $\left(50^{\circ} \mathrm{C}\right)$ untuk menguapkan metanol dan menghasilkan ekstrak pekat $20^{\circ}$ brix. Serutan kayu secang dan hasil ekstrak kayu secang dapat dilihatpada Gambar 6.

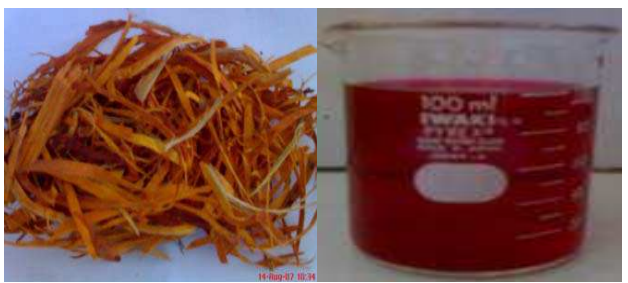

Gambar 6. Serutan Kayu Secang dan Hasil Ekstrak Secang

\subsection{Proses Pembuatan Formulasi Nanoemulsi}

Tabel 11a. Formulasi Nanoemulsi Ulangan 1.

\begin{tabular}{|c|c|c|c|}
\hline No & Formulasi Nanoemulsi & Formula & Keterangan \\
\hline \multirow[t]{4}{*}{1} & Formulasi Span20 & 1 & Terjadi pengendapan \\
\hline & & 2 & Terjadi pengendapan \\
\hline & & 3 & Terjadi pengendapan \\
\hline & & & Pengendapan $\mathrm{F} 1<\mathrm{F} 2<\mathrm{F} 3$ \\
\hline \multirow[t]{4}{*}{2} & Formulasi Span80 & 1 & Terjadi pengendapan \\
\hline & & 2 & Terjadi pengendapan \\
\hline & & 3 & Terjadi pengendapan \\
\hline & & & Pengendapan $\mathrm{F} 1<\mathrm{F} 2<\mathrm{F} 3$ \\
\hline \multirow[t]{3}{*}{3} & Formulasi Tween20 & 1 & Terjadi pengendapan \\
\hline & & 2 & $\begin{array}{l}\text { Terjadi pengendapan } \\
\text { Pengendapan F1 > F2 }\end{array}$ \\
\hline & & 3 & Tidak ada pengendapan \\
\hline \multirow[t]{4}{*}{4} & Formulasi Tween80 & 1 & Terjadi pengendapan \\
\hline & & 2 & Terjadi pengendapan \\
\hline & & & Pengendapan F1 > F2 \\
\hline & & $\begin{array}{l}3 \\
1\end{array}$ & $\begin{array}{l}\text { Tidak ada pengendapan } \\
\text { Tidak ada pengendapan }\end{array}$ \\
\hline \multirow[t]{3}{*}{5} & Formulasi Span20.Span80 & $\begin{array}{l}1 \\
2\end{array}$ & $\begin{array}{l}\text { IIdak ada pengendapan } \\
\text { Terjadi pengendapan }\end{array}$ \\
\hline & & 3 & Terjadi pengendapan \\
\hline & & & Pengendapan F2 < F3 \\
\hline \multirow[t]{4}{*}{6} & Formulasi & 1 & Terjadi pengendapan \\
\hline & Span20.Tween20 & 2 & Terjadi pengendapan \\
\hline & & 3 & Terjadi pengendapan \\
\hline & & & Pengendapan F1 > F2 > F3 \\
\hline \multirow[t]{3}{*}{7} & Formulasi & 1 & Terjadi pengendapan \\
\hline & Span20.Tween80 & 2 & $\begin{array}{l}\text { Terjadi pengendapan } \\
\text { Pengendapan } \mathrm{F} 1<\mathrm{F} 2\end{array}$ \\
\hline & & 3 & Tidak ada pengendapan \\
\hline \multirow[t]{4}{*}{8} & Formulasi & 1 & Terjadi pengendapan \\
\hline & Span80.Tween20 & 2 & Terjadi pengendapan \\
\hline & & & Pengendapan F1 < F2 \\
\hline & & 3 & Tidak ada pengendapan \\
\hline \multirow[t]{4}{*}{9} & Formulasi & 1 & Terjadi pengendapan \\
\hline & Span80.Tween80 & 2 & Terjadi pengendapan \\
\hline & & & Pengendapan F1 > F2 \\
\hline & & 3 & Tidak ada pengendapan \\
\hline \multirow[t]{4}{*}{10} & Formulasi & 1 & Terjadi pengendapan \\
\hline & Tween20.Tween80 & 2 & Terjadi pengendapan \\
\hline & & & Pengendapan F1 > F2 \\
\hline & & 3 & Tidak ada pengendapan \\
\hline
\end{tabular}


Tabel 11b. Formulasi Nanoemulsi Ulangan 1.

\begin{tabular}{|c|c|c|c|}
\hline No & Formulasi Nanoemulsi & Formula & Keterangan \\
\hline \multirow[t]{4}{*}{1} & Formulasi Span20 & 1 & Terjadi pengendapan \\
\hline & & 2 & Terjadi pengendapan \\
\hline & & 3 & Terjadi pengendapan \\
\hline & & & Pengendapan $\mathrm{F} 1<\mathrm{F} 2<\mathrm{F} 3$ \\
\hline \multirow[t]{4}{*}{2} & Formulasi Span80 & 1 & Terjadi pengendapan \\
\hline & & 2 & Terjadi pengendapan \\
\hline & & 3 & Terjadi pengendapan \\
\hline & & & Pengendapan $\mathrm{F} 1<\mathrm{F} 2<\mathrm{F} 3$ \\
\hline \multirow[t]{4}{*}{3} & Formulasi Tween20 & 1 & Terjadi pengendapan \\
\hline & & 2 & Terjadi pengendapan \\
\hline & & & Pengendapan F1 > F2 \\
\hline & & 3 & Tidak ada pengendapan \\
\hline \multirow[t]{4}{*}{4} & Formulasi Tween80 & 1 & Terjadi pengendapan \\
\hline & & 2 & Terjadi pengendapan \\
\hline & & & Pengendapan F1 > F2 \\
\hline & & 3 & Tidak ada pengendapan \\
\hline \multirow[t]{4}{*}{5} & Formulasi Span20.Span80 & 1 & Tidak ada pengendapan \\
\hline & & 2 & Terjadi pengendapan \\
\hline & & 3 & Terjadi pengendapan \\
\hline & & & Pengendapan F2 < F3 \\
\hline \multirow[t]{4}{*}{6} & Formulasi Span20.Tween20 & 1 & Terjadi pengendapan \\
\hline & & 2 & Terjadi pengendapan \\
\hline & & 3 & Terjadi pengendapan \\
\hline & & & Pengendapan F1 > F2 > F3 \\
\hline \multirow[t]{4}{*}{7} & Formulasi Span20.Tween80 & 1 & Terjadi pengendapan \\
\hline & & 2 & Terjadi pengendapan \\
\hline & & & Pengendapan F1 < F2 \\
\hline & & 3 & Tidak ada pengendapan \\
\hline \multirow[t]{4}{*}{8} & Formulasi Span80.Tween20 & 1 & Terjadi pengendapan \\
\hline & & 2 & Terjadi pengendapan \\
\hline & & & Pengendapan F1 < F2 \\
\hline & & 3 & Tidak ada pengendapan \\
\hline \multirow[t]{4}{*}{9} & Formulasi Span80.Tween80 & 1 & Terjadi pengendapan \\
\hline & & 2 & Terjadi pengendapan \\
\hline & & & Pengendapan F1 > F2 \\
\hline & & 3 & Tidak ada pengendapan \\
\hline \multirow[t]{4}{*}{10} & Formulasi & 1 & Terjadi pengendapan \\
\hline & Tween20.Tween80 & 2 & Terjadi pengendapan \\
\hline & & & Pengendapan F1 > F2 \\
\hline & & 3 & Tidak ada pengendapan \\
\hline
\end{tabular}

Keterangan: Formulasi yang terjadi pengendapan tidak dilakukan pengujian lanjut, karena bukan formulasi terbaik.

Untuk tiap formulasi nanoemulsi yang dibuat menggunakan ekstrak secang dengan persentase yang tetap yakni $10 \%$ dari berat formula, emulsifier yang digunakan adalah Span20, Span80, Tween20 dan Tween80 dengan persentase 2,5\%, 5\% dan 10\% dari berat formula untuk formulasi tunggal dan 1,25\%, 2,5\% dan $5 \%$ dari berat formula untuk formulasi ganda, sedangkan zat pelarut yang digunakan adalah akuades dengan persentase $87,50 \%, 85,00 \%$ dan $80,00 \%$ dari berat formula.

Formulasi yang dibuat ada dua yaitu formulasi tunggal dan formulasi ganda. Formulasi tunggal adalah: Formulasi Span20, formulasi Span80, formulasi Tween20 dan formulasi Tween80.Formulasi ganda adalah: Formulasi Span20-Span80, formulasi Span20-Tween20, formulasi Span20-Tween80, formulasi Span80-Tween20, formulasi Span80-Tween80 dan formulasi Tween20-Tween80. Formulasi tunggal dan formulasi 
ganda, masing-masing akan dibuat tiga formula yaitu: Formula 1, formula 2 dan formula 3 , dan dilakukan dua kali pengulangan (Tabel 11).

Sehingga dari hasil pengamatan tersebut, maka dapat ditentukan formula yang terpilih dari setiap formulasi, formula tersebut seperti Tabel 12.

Tabel 12. Formula Terpilih

\begin{tabular}{clc}
\hline No & \multicolumn{1}{c}{ Formulasi Nanoemulsi } & Formula \\
\hline 1 & Formulasi Tween20 (10\%) & 3 \\
2 & Formulasi Tween80 (10\%) & 3 \\
3 & Formulasi Span20-Span80 (1,25\%) & 1 \\
4 & Formulasi Span20-Tween80 (5\%) & 3 \\
5 & Formulasi Span80-Tween20 (5\%) & 3 \\
6 & Formulasi Span80-Tween80 (5\%) & 3 \\
7 & Formulasi Tween20-Tween80 (5\%) & 3 \\
\hline
\end{tabular}

Kemudian dilakukan pengujian untuk analisa lanjut, pengujian yang dilakukan adalah: pengujian ukuran partikel, zetapotensial/stabilitas emulsi dan indeks polidispersitas. Formula tepilih jika secara visual/kasat mata atau pengamatan secara langsung memenuhi kriteria antara lain: Tidak terjadi pengendapan, tidak terjadi penggumpalan, tidak terjadi pemisahan fase dan campurannya homogen.

\subsection{Karakteristik Pengujian Ukuran Partikel (Particle Size Analyzer)}

Ukuran partikel adalah karakteristik paling penting dalam sistem nanoemulsi, karena ukuran partikel mempengaruhi kestabilan sistem nanoemulsi. Ukuran partikel dari suatu nanoemulsi biasanya dinyatakan sebagai diameter dari globul-globul dalam fase internal (Mohanraj dan Chen, 2005). Ukuran partikel bergantung pada jenis dan persentase emulsifier dan adanya penambahan zat tambahan, jika ukuran partikel fase internal lebih kecil, sistem nanoemulsi menjadi lebih stabil, dan diperkuat (Tan dan Nakajima, 2005) yang menyatakan faktor yang berpengaruh terhadap ukuran partikel antara lain rasio fase minyak dan fase air, jenis dan persentase emulsifier. Penentuan distribusi ukuran partikel bertujuan untuk mempelajari pola persebaran dari ukuran partikel.

Ukuran diameter partikel dan distribusi ukuran partikel nanoemulsi zat pewarna alam ekstrak kayu secang ditentukan dengan Particle Size Analyzer Model Delsa ${ }^{\mathrm{TM}}$ Nano. Ukuran diameter partikel nanoemulsi dinyatakan oleh rata-rata diameter berdasarkan number distribution. Hasil pengukuran diameter ukuran partikel disajikan pada Tabel 13.

Tabel 13. Hasil Pengujian Particle Size Analyzer

\begin{tabular}{clc}
\hline No & \multicolumn{1}{c}{ Formula Nanoemulsi } & $\begin{array}{c}\text { Ukuran Partikel Diameter } \\
\text { rata-rata (nm) }\end{array}$ \\
\hline 1 & Formulasi Tween20 (10\%) & $182.5 \pm 51.5 \mathrm{~b}$ \\
2 & Formulasi Tween80 (10\%) & $254.7 \pm 67.1 \mathrm{a}$ \\
3 & Formulasi Span20-Span80 $(1,25 \%)$ & $68.1 \pm 19.3 \mathrm{~d}$ \\
4 & Formulasi Span20-Tween80 (5\%) & $63.5 \pm 15.9 \mathrm{~d}$ \\
5 & Formulasi Span80-Tween20 (5\%) & $85.7 \pm 24.4 \mathrm{~cd}$ \\
6 & Formulasi Span80-Tween80 (5\%) & $94.9 \pm 26.3 \mathrm{c}$ \\
7 & Formulasi Tween20-Tween80 (5\%) & $159.2 \pm 45.4 \mathrm{~b}$ \\
\hline
\end{tabular}


Keterangan : Angka (pada baris yang sama) yang diikuti huruf yang sama tidak berbeda nyata menurut uji Duncan pada taraf nyata $5 \%$

Dari hasil pengukuran diameter ukuran partikel Tabel 13, diperoleh nilai untuk ketujuh formulasi nanoemulsi berada pada kisaran $63.5 \mathrm{~nm}$ sampai dengan $254.7 \mathrm{~nm}$. Nilai ukuran partikel yang terendah adalah formulasi Span20-Tween80 (5\%) dengan nilai63.5 nm, sedangkan nilai ukuran partikel yang tertinggi adalah formulasi Tween80 (10\%) dengan nilai $254.7 \mathrm{~nm}$.

Hasil pengukuran diameter ukuran partikel menunjukkan formulasi tunggal yang menggunakan emulsifier Tween dan formulasi ganda kombinasi Tween-Tween menghasilkan formula nanoemulsi dengan diameter ukuran partikel lebih besar (>100 nm) dibandingkan formulasi ganda yang menggunakan kombinasi emulsifier Span-Tween, yang menghasilkan formula nanoemulsi dengan diameter ukuran partikel lebih kecil $(<100$ $\mathrm{nm}$ ), hal ini disebabkan jenis emulsifier Tween bersifat hidrofilik, sedangkan jenis emulsifier Span bersifat lipofilik.

Formulasi tunggal Tween20 menghasilkan formula nanoemulsi dengan diameter ukuran partikel lebih kecil dibandingkan dengan diameter ukuran partikel formulasi tunggal Tween80, hal ini disebabkan tingkat sifat hidrofilik Tween20 lebih kecil dibandingkan tingkat sifat hidrofilik Tween80, meskipun nilai persentasenya sama $10 \%$. Formulasi tunggal Tween20 dan Tween80 menghasilkan formula nanoemulsi dengan diameter ukuran partikel yang lebih besar dibandingkan dengan diameter ukuran partikel formulasi ganda kombinasi Tween20-Tween80, hal ini disebabkan adanya perbedaan jenis dan persentase emulsifier antara formulasi tunggal dan formulasi ganda. Menurut hasil penelitian Purwantiningsih et al (2010), menunjukkan bahwa persentase ukuran diameter partikel nano yang terbentuk pada penggunaan Tween80 lebih besar. Tingkat keseragaman ukurannya lebih baik. Kisaran persentase ukuran diameter partikel nano menggunakan Tween 80 adalah $150 \mathrm{~nm}$.

Besarnya nilai diameter ukuran partikel pada formulasi tunggal (Tween20 danTween80) serta formulasi ganda kombinasi (Tween20-Tween80), disebabkan karena persentase dari emulsifier Tween yang sangat kecil (5\% dan 10\%). Hal ini terjadi dikarenakan adanya penurunan absorpsi surfaktan diantara permukaan minyak-air, dan peningkatan tegangan permukaan dalam sistem sehingga mendukung terbentuknya nanoemulsi dengan diameter ukuran partikel lebih besar. Menurut hasil penelitian Salim et al (2011), penurunan diameter ukuran partikel yang signifikan terlihat dengan tingginya konsentrasi emulsifier Tween (Tween20 dan Tween80) hingga mencapai 40\% yang menghasilkan diameter ukuran partikel 60,210 nm. Data tersebut menunjukkan bahwa penggunaan konsetrasi Tween (Tween20 dan Tween80) yang semakin tinggi/meningkat akan menurunkan diameter ukuran partikel nanoemulsi. 
Sedangkan persentase emulsifier formulasi ganda kombinasi Span-Span memberikan hasil yang baik adalah persentase 1,25\%, namun tidak demikian pada persentase $2,5 \%$ dan $5 \%$. jumlah persentase emulsifier yang berlebihan juga akan dapat menimbulakan Oswald ripening, yaitu menggumpalnya emulsifier dan partikel ekstrak secang itu sendiri untuk formulasi ganda kombinasi Span-Span. Persentase emulsifier formulasi ganda kombinasi Span-Tween yang memberikan hasil yang baik adalah persentase $5 \%$, namun tidak demikian pada persentase $1,25 \%$ dan $2,5 \%$, hal ini terlihat dengan adanya penggumpalan dan pengendapan. Ini diduga oleh sedikitnya jumlah persentase emulsifier, sehingga tidak cukup untuk mengurangi tegangan antarmuka partikel-air. Jumlah persentase emulsifier yang sedikit dapat mengakibatkan partikel menggumpal membentuk agregat untuk formulasi ganda kombinasi Span-Tween. Menurut Helmiyati et al (2009), konsentrasi surfaktan berpengaruh terhadap ukuran diameter partikel. Konsentrasi surfaktan semakin besar, ukuran diameter partikel yang didapatkan semakin kecil, hal ini disebabkan semakin banyak misel yang terbentuk, sehingga ukuran diameter partikel yang dihasilkan lebih kecil.

Pengaruh jenis dan persentase emulsifier berpengaruh terhadap hasil diameter ukuran partikel. Hasil pengukuran diameter ukuran partikel menunjukkan bahwa jenis emulsifier yang baik digunakan adalah formulasi ganda kombinasi antara Span-Span dan Span-Tween, hal ini dikarenakan oleh sifat ekstrak secang yang lipofilik sehingga membutuhkan kombinasi surfaktan yang bersifat lipofilik dan lipofilik-hodrofilik. Tujuannya adalah untuk menjembatani antara partikel ekstrak secang yang bersifat lipofilik dengan air. Menurut hasil penelitian Shannora dan Hamdan (2012), jenis dan konsentrasi emulsifier dan rasio fase minyak:fase air berpengaruh signifikan terhadap ukuran diameter partikel nanoemulsi. Semakin sedikit fase minyak yang digunakan dalam penyiapan larutan nanoemulsi, maka ukuran diameter partikel menjadi semakin kecil. Sebaliknya, jumlah fase minyak semakin banyak, maka luas permukaan minyak yang harus dilindungi oleh emulsifier juga semakin besar, hal ini berakibat kemampuan emulsifier untuk menstabilkan pembentukan droplet menjadi terbatas dan cenderung untuk mengalami koalesense, sehingga droplet nanoemulsi yang terbentuk berdiameter relatif lebih besar.

Hasil analisis ragam $(\alpha=0,05)$ menunjukkan bahwa perlakuan atau tiap-tiap formula memberikan pengaruh yang berbeda nyata $(p<0.05)$ terhadap nilai ukuran partikel ketujuh formula dari formulasi nanoemulsi ekstrak secang. Hasil uji lanjut Duncan $(\alpha=0,05)$ menunjukkan bahwa rata-rata nilai ukuran partikel ketujuh formula pada formulasi nanoemulsi ekstrak secang berbeda nyata. Berdasarkan hasil uji lanjut Duncan menunjukkan bahwa angka yang diikuti dengan huruf yang sama tidak berbeda nyata. 
Nilai rata-rata terendah adalah formulasi Span20-Tween80 (5\%), dan nilai rata-rata tertinggi adalah formulasi Tween80 (10\%).

\subsection{Karakteristik Pengujian Indeks Polidispersitas (Distribusi Ukuran Partikel)}

Indeks polidispersitas adalah parameter yang menyatakan distribusi ukuran partikel dari sistem nanoemulsi yang nilainya 0,01 sampai 0,7 menyatakan sistem nanoemulsi dengan distribusi ukuran partikel yang sempit, sedangkan nilai indeks polidispersitas yang lebih besar dari 0,7 menyatakan sistem nanoemulsi dengan distribusi ukuran partikel yang sangat luas (Nidhin, 2009), dan diperkuat (Yuan, 2008) yang menyatakan semakin kecil nilai indeks polidispersitas menunjukkan distribusi ukuran partikel semakin sempit, yang berarti semakin homogen.

Ukuran Indeks polidispersitas (distribusi ukuran partikel) nanoemulsi zat pewarna alam ekstrak kayu secang ditentukan dengan Particle Size Analyzer Model Delsa ${ }^{\mathrm{TM}}$ Nano. Distribusi ukuran partikel nanoemulsi dinyatakan sebagai indeks polidispersitas. Hasil pengukuran Indeks Polidispersitas disajikan pada Tabel 14.

Tabel 14. Hasil Pengujian Particle Size Analyzer

\begin{tabular}{clc}
\hline No & \multicolumn{1}{c}{ Formula Nanoemulsi } & Indeks Polidispersitas \\
\hline 1 & Formulasi Tween20 $(10 \%)$ & $0.187 \mathrm{e}$ \\
2 & Formulasi Tween80 $(10 \%)$ & $0.195 \mathrm{e}$ \\
3 & Formulasi Span20-Span80 $(1,25 \%)$ & $0.295 \mathrm{~cd}$ \\
4 & Formulasi Span20-Tween80 $(5 \%)$ & $0.782 \mathrm{a}$ \\
5 & Formulasi Span80-Tween20 $(5 \%)$ & $0.389 \mathrm{~b}$ \\
6 & Formulasi Span80-Tween80 $(5 \%)$ & $0.356 \mathrm{bc}$ \\
7 & Formulasi Tween20-Tween80 $(5 \%)$ & $0.240 \mathrm{de}$ \\
\hline
\end{tabular}

Keterangan : Angka (pada baris yang sama) yang diikuti huruf yang sama tidak berbeda nyata menurut uji Duncan pada taraf nyata $5 \%$

Hasil pengukuran untuk nilai indeks polidispersitas (Tabel 14) menunjukkan nilai indeks polidispersitas dari ketujuh formulasi nanoemulsi berada pada kisaran 0.187 sampai dengan 0.782 . Nilai indeks polidispersitas terendah adalah formulasi Tween20 (10\%) dengan nilai 0.187 , sedangkan nilai indeks polidispersitas yang tertinggi adalah formulasi Span20-Tween80 (5\%) dengan nilai 0.782. Hasil pengukuran indeks polidispersitas menunjukkan semua formulasi nanoemulsi memiliki nilai indeks polidispersitas kecil $(<0.7)$, baik untuk formulasi tunggal maupun formulasi ganda, hal ini menyatakan bahwa secara umum semua formulasi nanoemulsi memenuhi standar distribusi ukuran partikel sebagai sistem nanoemulsi.

Perbedaan jenis dan persentase emulsifier tidak berpengaruh signifikan terhadap distribusi ukuran partikel nanoemulsi, yang ditunjukkan dengan nilai indeks polidispersitas berkisar antara 0,187 sampai 0,782. Ini menunjukkan formulasi tunggal jenis emulsifier Tween dan formulasi ganda kombinasi Span-Span, Span-Tween dan Tween-Tween dengan persentase $1,25 \%, 5 \%$ dan $10 \%$ sudah dapat menghasilkan formula nanoemulsi yang memiliki distribusi ukuran partikel relatif sempit, yang berarti diameter ukuran partikel 
nanoemulsi relatif homogen. Menurut Yuan et al (2008), nilai indeks polidispersitas menunjukkan penyebaran distribusi ukuran partikel, semakin kecil nilai indeks polidispersitas menunjukkan distribusi ukuran partikel semakin sempit, yang berarti ukuran diameter partikel semakin homogen. Dan menurut hasil penelitian Shannora dan Hamdan (2012), jenis dan konsentrasi emulsifier serta rasio fase minyak dan fase air tidak memberikan pengaruh yang signifikan terhadap distribusi ukuran partikel nanoemulsi, yang ditunjukkan pada nilai indeks polidispersitas berkisar 0,258 sampai 0,376.

Hasil analisis ragam $(\alpha=0,05)$ menunjukkan bahwa perlakuan atau tiap-tiap formula memberikan pengaruh yang berbeda nyata $(p<0.05)$ terhadap nilai indeks polidispersitas ketujuh formula pada formulasi nanoemulsi ekstrak secang. Hasil uji lanjut Duncan $(\alpha=0,05)$ menunjukkan bahwa rata-rata nilai indeks polidispersitas ketujuh formula pada formulasi nanoemulsi ekstrak secang berbeda nyata. Berdasarkan hasil uji lanjut Duncan menunjukkan bahwa angka yang diikuti dengan huruf yang sama tidak berbeda nyata. Nilai rata-rata terendah adalah formulasi Tween20 (10\%), nilai rata-rata tertinggi adalah formulasi Span20-Tween80 (5\%).

\section{Kesimpulan}

Keseluruhan formula yang diperoleh dari formulasi nanoemulsi dengan menggunakan ekstrak secang, emulsifier dan aquades, dihasilkan tujuh formulasi nanoemulsi yang terbaik untuk dilakukan pengujian dan analisa lanjut, karena dari hasil pengamatan secara visual ketujuh fomulasi tersebut tidak terjadi pengendapan, tidak terjadi penggumpalan, tidak terjadi pemisahan fase dan homogen secara fisik. Hasil penelitian awal dengan pengamatan secara visual/kasat mata, menunjukkan bahwa formulasi yang terbaik adalah formulasi Tween20 (10\%), formulasi Tween80 (10\%), formulasi Span20-Span80 (1,25\%), formulasi Span20-Tween80 (5\%), formulasi Span80Tween20 (5\%), formulasi Span80-Tween80 (5\%), dan formulasi Tween20-Tween80 (5\%).

Hasil pengukuran ukuran partikel, menunjukkan formulasi tunggal menggunakan emulsifier Tween dan formulasi ganda kombinasi Tween-Tween menghasilkan formula nanoemulsi dengan diameter ukuran partikel lebih besar (>100 nm), formulasi ganda kombinasi Span-Span dan Span-Tween menghasilkan formula nanoemulsi dengan diameter ukuran partikel lebih kecil $(<100 \mathrm{~nm})$. Hasil pengukuran nilai distribusi ukuran partikel menunjukkan nilai indeks polidispersitas dari ketujuh formulasi nanoemulsi antara 0,187 sampai 0,782 , ini menyatakan secara umum semua formulasi nanoemulsi memenuhi standar distribusi ukuran partikel sebagai sistem nanoemulsi.

\section{Daftar Pustaka}

Bakan, J.A. 1995. Dalam Swarbrick, J., J.C. Boylan (eds.). 1995. Encyclopedia of pharmaceuticaltechnology. Volume Marcel Dekker Inc, New York: 335-369. 
Helmiyati, emil, B. dan Nitri, A. 2009. Pengaruh Konsentrasi Surfaktan, Inisiator dan Teknik Polimerisasi Terhadap Distribusi Ukuran Partikel. J. Sains. 13(1): 59-64.

Korting (a), H. C. \& Korting (b), M. S. (2010). Carriers in the Topical Treatment of Skin Dsease. In Korting, Monika Schafer (Ed). Drug Delivery. Berlin: Springer-Verlag Berlin Heidelberg, 446. December 20, 2010.

Mohanraj, VJ., dan Y Chen. (2005). Nano particles-Areview. Tropical Journal of Pharmaceutical Research, 5(1), 561-573.

Nidhin, M., Indumathy, R., Sreeram, KJ., dan Nair, B., U. (2009). Synthesis of Iron Oxide Nanoparticles of Narrow Size Distribution on Polysaccharide Templates. Buletin. Materaial Scence. 31(1), 93-96

Salim, N., Basri, M., Rahman, M.B., Abdullah, D.K. dan Salleh, A.B. (2011). Phase Behaviour, Formation and Characterization of Palm-Based Esters Nanoemulsion Formulation containing Ibuprofen. J. Nonomedic Nanotechnol. 2(4): 1-5.

Shannora, Y. dan Hamdan. 2012. Karakteristik Nanoemulsi Minyak Sawit Merah yang Disiapkan Dengan High Pressure Homogenizer. Prosiding InSINas. PG-27: 0656.

Tan CP, Nakajima M. (2005). $\beta$-Carotene nanodispersions: preparation, characterization and stability evaluation. Food Chemistry 92:661-671.

Yuan Y, Gao Y, Zhao J, Mao L. (2008). Characterization and stability evaluation of $\beta$ carotene nanoemulsions prepared by high pressure homogenization under various emulsifying conditions. Food Research International 41:61-68. 